\title{
УдК 658.8:378
}

DOI: https://doi.org/10.32782/2304-0920/5-84-10

Буднік О. М.

Поліський національний університет

\section{КОМПАІМЕНТАРНЕ ПОЄАНАННЯ КААСИЧНИХ ТА ІННОВАЦІЙНИХ МЕТОАІВ ВИКААААННЯ В СУЧАСНІЙ ПРОФЕСІЙНІЙ ОСВІТІ}

\begin{abstract}
Головним пріоритетом сучасної вищої освіти є її спрямування до європейського освітнього простору, у зв'язку із цим поряд із класичними науковими прийомами значною мірою посилюється роль інноваційних та інтерактивних методів і методик навчання. Варіативність інновацій в освіті сприяє проведенню занять на якісно новому рівні, що формує у студентів навички критичного мислення, дає їм змогу навчитися збирати необхідну інформацію, систематизувати та аналізувати їі, вирішувати складні завдання, розвивати логіку та стратегічне мислення, застосовувати та розкривати власний потенціал. Особливо актуальною під час викладання дисциплін маркетингового циклу є методика роботи у фокус-групах, застосування якої дає змогу студентам ефективно взаємодіяти i, як результат, формувати нові, цікаві й нестандартні пропозиції вирішення складних завдань.

Ключові слова: класичні наукові прийоми, інноваційні та інтерактивні методи викладання, критичне мислення, фокус-групи.
\end{abstract}

Постановка проблеми. Економічно сильна та розвинута держава потребує кваліфікованих фахівців, що володіють не лише теоретичними, а й практичними знаннями та мають навики вирішення основних проблем підприємства для розкриття його потенціалу і підвищення конкурентоспроможності. Сьогодні внаслідок відсутності достатньої кількості власних ресурсів фірми закуповують прогресивні технології, новітню техніку, обладнання, але вкрай гостро при цьому відчувають нестачу спеціалістів, здатних їх опанувати та застосувати. Отже, підготовка професіоналів різних сфер та секторів економіки є актуальним завданням сучасної професійної освіти.

Аналіз останніх досліджень i публікацій. Використання інноваційних технологій в освітньому просторі $є$ дуже актуальною проблемою. Вагомі наукові здобутки 3 даного питання мають Н. Артикуца, Г. Багієв, К. Баханов, Х. Бахтіярова, Ю. Бистрова, П. Вудс, А. Гін, І. Горобець, Н. Грицак, В. Зіновчук, М. Кляп, Л. Козак, А. Коломієць, І. Лилик, Г. Маковська, О. Мирошниченко, В. Наумов, М. Окландер, Е. Пронський, П. Романова, О. Фатхутдінова, В. Циганок, Н. Чухрай тощо. Водночас застосування інновацій для формування високопрофесійного та конкурентоспроможного фахівця, адаптивного до швидкозмінних умов сьогодення, потребує проведення глибших досліджень у цій сфері.

Мета статті. Головною метою цієї роботи є обгрунтування важливості поєднання традиційних (класичних) та новітніх методів викладання дисциплін маркетингового циклу в сучасному мейнстрімі.

Виклад основного матеріалу. Застосування в освітньому просторі навчальних моделей розвинутих країн вимагає від викладача не лише підвищення власного професійного рівня та постійного збільшення багажу знань, а й уміння донести інформацію до студента, тобто сучасний рівень викладання зумовлює потребу постійної адаптивності, гнучкості та саморозвитку педагога. Надважливим завданням викладача при цьому є вміння поєднувати теоретичні, базові основи дисципліни з практичним їх застосуванням, що сприятиме можливості якісно нового засвоєння отриманих знань, адже застосування новітніх підходів, методів та принципів викладання є принципово важливою компонентою сучасності. Нині існує об'єктивна потреба формування прогресивно оновленого освітнього середовища, що передбачає підготовку спеціалістів, орієнтованих на реальні потреби ринку праці, зі сформованими у них soft skills, тобто здатністю до вивчення проблеми, їі аналізу, продукування ефективних та креативних рішень, праці в колективі. Це сприятиме формуванню затребуваних спеціалістів нової формації.

Дещо дискутивною є думка Н. Грицак, яка зауважує, що інноваційне навчання виступає опозицією до традиційного навчання, оскільки передбачає зміну пріоритетів освіти [9, с. 188-199]. Уважаємо, що інноваційне і класичне (традиційне) навчання має бути компліментарно поєднаним та взаємодоповнюючим. Адже сучасний рівень суспільного розвитку вимагає від працівників вищих навчальних закладів перетворення навчального процесу на плідну та конструктивну співпрацю викладача і студентів, що дасть змогу студентству не лише опанувати дисципліну, а й досягти відповідного рівня саморозвитку. У зв'язку із цим слушною є наукова позиція I. Горобець та Г. Маковської, які наголошують, що сучасний викладач має намагатися співіснувати 3 новітніми формами, а не конкурувати, що збільшить його авторитет серед студентів і дасть йому можливість безупинно професійно зростати [8, с. 56-59]. До того ж колектив авторів на чолі з Х. Бахтіяровою відзначає, що надзвичайно важливим $€$ особистісне становлення і виявлення внутрішніх резервів розвитку студента, молодої людини - представника тієї нової генерації, що невдовзі візьме на себе відповідальність за майбутне країни і творитиме нову архітектоніку українського суспільства [10].

Як зауважують О. Марченко та Н. Сидоренко, освіта в сучасному глобалізованому світі - це складний процес формування особистості. Відповідно, усталені освітні парадигми зазнають змін, що потенційно зумовлюе появу нових форм та видів навчальної діяльності [2]. В арсеналі сучасного викладача достатньо інноваційних методів організації навчального процесу та формування компетентностних характеристик майбутнього спеціаліста, які передбачають упровадження новацій освітньої діяльності в навчальний процес, що вбачається головною умовою під час формування професорсько-викладацького складу [21, с. 214-218]. Так, Ю. Бистрова пропонує інноваційну навчальну технологію та сучасні методи 
викладання розглядати як сукупність оригінальних способів і прийомів спільної діяльності суб'єктів освітнього процесу, спрямованих на досягнення мети навчання, розвитку особистості та креативно-фахового здобуття знань і компетенцій відповідно до завдань підготовки професіоналів нового часу [6]. Важливо відзначити, що під час такого навчання студент вступає у діалог із викладачем, виконує творчі, проблемні завдання, відповідає на запитання, що розвивають аналітичне і критичне мислення, ставить запитання викладачеві та іншим учасникам, тобто активізується творча співпраця викладача зі студентами (разом вирішують проблеми, моделюють ситуації) [5]. У зв'язку із цим значно посилюється роль інтерактивного навчання, внаслідок якого відбувається взаємодія студентів, а викладач при цьому виступає організатором процесу навчання. Дослідження спеціалізованої літератури дає змогу виокремити головні ознаки інтерактиву (рис. 1).

Важливість використання інтерактивних технологій підготовки фахівців обгрунтовується тим, що студенти отримують змогу розв'язувати складні завдання і задачі на основі аналізу даних, вивчати протиріччя, висловлювати альтернативні думки, приймати виважені рішення, брати участь у дискусіях; моделювати ситуації, збагачувати власний досвід; учитися будувати конструктивні відносини в групі, визначати своє місце в ній, уникати конфліктів або розв'язувати їх, шукати компроміси, прагнути до діалогу, знаходити спільне вирішення проблеми; розвивати навички проєктної діяльності, самостійної роботи, виконувати творчі роботи, застосовувати власний потенціал та креативність. У результаті використання інтерактивних методів навчання дає змогу студентам сконцентруватися на виконанні бажаного завдання і спонукає їх до вирішення певної проблеми, на основі узагальнення набутих знань і власної логіки сформувати стратегічне бачення вирішення проблемних ситуацій. Ключові особливості навчання із застосуванням інтерактиву наведено на рис. 2.

У Поліському національному університеті під час викладання дисциплін маркетингового циклу найчастіше використовують метод роботи у фокусгрупах. Центр соціальних та маркетингових досліджень SOCIS виділяє декілька видів фокус-групових дискусій (рис. 3).

На практиці під час застосування методики фокус-груп студенти поділяються на невеликі підгрупи (кількість студентів у яких варіюється). Кожна фокус-група отримує завдання вибрати відомий бренд та провести маркетингове дослідження відповідно до певного плану.

Для проведення повноцінного аналізу студенти проводять збір «вторинної» інформації з використанням спеціалізованої літератури та Інтернетджерел і «первинної» інформації з розробленням власної анкети та проведенням соціометричного
Ознаки

розтирення
пізнавальної
активності

Джерело: узагальнено на основі [10]

\section{Характеристика} кожен з учасників навчального процесу заохочений до активного пізнання через багатосторонню комунікацію, групову роботу та творчу взаємодію

Характеристика
Особливості

Рис. 2. Ключові особливості інтерактиву

Джерело: узагальнено на основі [19, с. 120] 
Види

Характеристика

\begin{tabular}{|c|c|}
\hline $\begin{array}{r}e c c \\
2 p\end{array}$ & $\begin{array}{lllll}\text { окус-групи, що працюють із реальними ситуаціями, } \\
\text { аближеними до стандартних життєвих обставин } & & \\
\end{array}$ \\
\hline $\begin{array}{l}\text { seat } \\
\text { гp }\end{array}$ & $\begin{array}{l}\text { відрізняються від звичайних фокус-груп тим, що в них основна увага } \\
\text { приділяється використанню різноманітних технік, спрямованих на } \\
\text { стимулювання творчого потенціалу учасників }\end{array}$ \\
\hline $\begin{array}{c}\text { мозковий } \\
\text { итурмм }\end{array}$ & $\begin{array}{l}\text { є різновидом креативних фокус-груп і використовується для генерації ідей } \\
\text { за рахунок використання низки технік, спрямованих на активацію } \\
\text { творчого мислення }\end{array}$ \\
\hline & $\begin{array}{l}\text { перехідна форма між індивідуальними та груповими методами якісних } \\
\text { досліджень, суть яких полягає у глибинному інтерв'юванні 4- } \\
6 \text { респондентів, що створює можливості для отримання детальної } \\
\text { інформації від кожного учасника (використовують даний метод у разі, } \\
\text { коли складно зібрати повну фокус-групу та за необхідності глибокого } \\
\text { аналізу точки зору респондентів) }\end{array}$ \\
\hline
\end{tabular}

\begin{tabular}{|c|c|}
\hline זpl & $\begin{array}{l}\text { використовуються у разі, коли потрібно нівелювати вплив думки } \\
\text { більшості на точку зору окремих учасників, а також у ситуаціях, коли } \\
\text { рівень конфлікту між ними настільки суттєвий, що перешкоджає } \\
\text { груповому обговоренню (у таких групах респонденти відповідають на } \\
\text { запитання, вони мають слухати відповіді інших респондентів, можуть } \\
\text { доповнювати їх, але їм не дозволено безпосередньо взаємодіяти) }\end{array}$ \\
\hline
\end{tabular}

\begin{tabular}{|c|l}
$\begin{array}{c}\text { конфліктнi } \\
\text { групи }\end{array}$ & $\begin{array}{l}\text { формуються } 3 \text { людей, у яких яскраво виражені протилежні погляди } \\
\text { (споживачі певної марки та споживачі конкуруючої марки), що провокує } \\
\text { ситуацію, коли кожен учасник намагається переконати супротивника i } \\
\text { часто супроводжується виникненням нових продуктивних ідей }\end{array}$ \\
\hline
\end{tabular}

\begin{tabular}{|c|} 
delphy- \\
zpynu
\end{tabular}

Рис. 3. Види фокус-групових дискусій

Джерело: узагальнено на основі [3]

опитування а) споживачів вибраного продукту та б) експертів. Опрацьований матеріал систематизується, аналізується, групується, на основі чого формуються результати. У ході проведення даного аналізу вивчається ринкова кон'юнктура, проводиться аналіз конкурентів підприємства, досліджується асортимент, аналізуються система ціноутворення та особливості використання цінових знижок, приділяється окрема увага логістиці, детально вивчається комунікаційна діяльність. На завершення майбутні фахівці-маркетологи мають розробити низку власних пропозицій щодо вдосконалення маркетингу вибраної торгової марки 3 обов'язковою їх презентацією. У ході презентації інші підгрупи задають питання або коментують пропозиції. Зазвичай робота у фокус-групах зі студентами відбувається в декілька етапів (рис. 4).

Досвід нашої роботи показує, що під час проведення таких занять часто необхідно використовувати індивідуальний підхід до підгруп, оскільки одні намагаються виконати завдання вчасно i швидко, інші витрачають більше часу на пошук
Етапи роботи у фокус-групах

планування

Рис. 4. Алгоритм роботи зі студентами

Джерело: розроблено на основі [10]
Результат

формування всебічно розвиненої особистості 


\section{Створення ситуаціï успіху}

\begin{tabular}{|c|c|}
\hline $\begin{array}{c}\text { авансування успішності } \\
\text { результату }\end{array}$ & $\begin{array}{l}\text { викладач висловлює тверду переконаність у тому, що } \\
\text { студенти впораються з поставленим завданням }\end{array}$ \\
\hline латентний інструктаж & послідовність виконання отриманих завдань \\
\hline мотивація & обгрунтовується користь, яку принесе виконання справи \\
\hline персональна винятковість & наголос на важливості особистісних зусиль студентів \\
\hline мобілізація активності & спонукає до виконання конкретних дій та завдань \\
\hline результативність & презентація отриманих результатів \\
\hline
\end{tabular}

Рис. 5. Створення ситуації успіху під час роботи у фокус-групах

Джерело: узагальнено на основі [10]

та опрацювання інформації. При цьому їхні дослідження бувають подекуди кращими та глибшими [7, с. 278-280]. Варто наголосити на тому, що студенти, працюючи у фокус-групах, «розкривають» власний потенціал, генеруючи та продукуючи нові, цікаві, креативні та нестандартні ідеї.

Повною мірою поділяємо думку Г. Коржова про те, що краще застосовувати декілька методів опрацювання матеріалу, що дає змогу здійснювати перевірку достовірності результатів і підвищує якість дослідження. Дослідник також наголошує на необхідності поєднання кількісних та якісних методів, що дасть змог зібрати більш різноманітну та цікаву інформацію, а також представити досліджуване явище з багатьох боків [11, с. 19-22].

Уважаємо, що, беззаперечно, існує потреба комбінування інтерактивних та інноваційних методів навчання з традиційними задля нівелювання ймовірності механічності сприйняття інтерактиву, що може призвести до втрати зацікавленості студентів у вирішенні поставлених проблем.
Висновки і пропозиції. Таким чином, упровадження інноваційних технологій у сферу викладання слід розглядати як закономірне явище, вагомою перевагою якого є взаємодія всіх учасників освітнього процесу й посилення практичної підготовки майбутніх фахівців. Особливо актуально це для випускників-маркетологів, що опинилися в умовах гострої конкуренції, адже роботодавець надає перевагу молодим спеціалістам із досвідом виконання професійних обов'язків у реальному бізнес-середовищі та з навичками колективної комунікації. Натомість викладання дисциплін маркетингового циклу на основі інтерактиву у форматі фокус-груп дає змог підвищити рівень засвоєння курсу, здобути практичні знання та отримати навички міжособистісного спілкування. У перспективі компліментарне поєднання класичного та інтерактивного подання матеріалу змінить позиції як викладача, так і студентів, оскільки вони отримають змогу стати рівноправними суб’єктами взаємодії в освітньому просторі.

\section{Список використаних джерел:}

1. Andrade Јого A.S., Duarte Adelaide P.S., Simoes Marta C.N. Education and health: welfare state composition and growth across country groups. Eastern Journal of European Studies. 2018. Vol. 9. Is. 2. P. 111-144.

2. Marchenko O., Sydorenko N. Higher education in the globalized world: modern trends in management, funding and quality assurance. Economic Annals-XXI. 2019. № 179(9-10). P. 53-65. DOI: https://doi.org/10.21003/ea.V179-05

3. SOCIS - центр соціальних та маркетингових досліджень : вебсайт. URL: https://socis.kiev.ua/ua (дата звернення: 02.11.2020).

4. Zinovchuk V. The Matrix Methods and Models in Marketing Analysis and Planning. Вісник Житомирського національного агроекологічного університету. 2016. № 1(54). С. 20-29.

5. Артикуца Н.В. Інноваційні методики викладання дисциплін у вищій юридичній освіті. URL: http://ekmair.ukma.edu. ua/bitstream/handle/123456789/2424/Artikutsa_Inov.pdf (дата звернення: 05.11.2020).

6. Бистрова Ю.В. Інноваційні методи навчання у вищій школі України Право та інноваційне суспільство. 2015. № 1(4). URL: http://apir.org.ua/ wp-content/uploads/2015/04/Bystrova.pdf (дата звернення: 11.11.2020).

7. Буднік О.М. Методологічні аспекти викладання маркетингу у вищому навчальному закладі. Глобальні та національні проблеми економіки. 2017. № 16. С. 278-280.

8. Горобець І.А., Маковська Г.Я. Інноваційні технології у викладанні іноземної мови професійного спрямування. Молодий вчений. 2018. № 3.2 (55.2). С. 56-59.

9. Грицак Н. Інноваційні підходи до вивчення зарубіжної літератури у вищій школі. Освітологічний дискурс. 2018. № 1-2 (20-21). С. 188-199.

10. Інноваційні технології навчання : навчальний посібник / відп. ред. Х.Ш. Бахтіярова. Кииів : НТУ, 2017. 172 с.

11. Коржов Г. Методи соціологічних досліджень. Маркетинг в Україні. 2020. № 4. С. 19-22.

12. Кравчина Т.В. Види інтерактивних методів навчання англійської мови для студентів технічних спеціальностей. Відкрите освітнє е-середовище сучасного університету. 2018. № 5. C. 140-145. URL: https://doi.org/10.28925/24140325.2018.5.140145

13. Кляп М. Інноваційні методи навчання у ВНЗ як інструмент інтернаціоналізації вищої освіти України. Вища освіта України. 2015. № 4. С. 45-53.

14. Козак Л.В. Дослідження інноваційних моделей навчання у вищій школі Освітологічний дискурс. 2014. № 1(5). С. $95-107$. URL: http://nbuv.gov.ua/UJRN/osdys_2014_1_11 (дата звернення: 22.10.2020).

15. Компетентнісний підхід у сучасній освіті: світовий досвід та українські перспективи. Бібліотека з освітньой політики / за заг. ред. О.В. Овчарук. Київ : К.І.С., 2004. 112 с.

16. Лилик I.В. Досвід впровадження інтерактивних методик викладання маркетингу. URL: https://core.ac.uk/download/ pdf/32619251.pdf (дата звернення: 16.10.2020).

17. Паламар С., Науменко М. Сторітелінг у професійній підготовці майбутніх педагогів: сучасні інструменти. Відкрите освітнє е-середовище сучасного університету. 2019. № 7. C. 48-55. URL: https://doi.org/10.28925/2414-0325.2019.7.5 
18. Пронський Е.А. Інтерактивні методи вивчення маркетингу / наук. кер. Л.Ю. Сагер. Еконолічні проблеми сталого розвитку : матеріали міжн. наук.-практ. конф. ім. проф. О.Ф. Балацького. Суми : СумДУ, 2016. № 2. С. 69-71.

19. Романова П.А. Побудова навчальної технології: індивідуально-типологічний підхід. Психолого-педагогічні аспекти реалізацї̈ сучасних методів навчання у вищій школі : навчальний посібник / за ред. М.В. Артюшиної, О.М. Котишової, Г.М. Романової. Київ : КНЕУ, 2007. 120 с.

20. Рясних Є., Савченко О. Маржинальний підхід до аналізу асортименту продукції підприємства. Маркетинг в Украйні. 2018. № 6. С. 35-44.

21. Циганок В.М., Буднік О.М., Гуля Ю.В. Теоретико-методологічні аспекти імплементації основ маркетингу в навчальний процес. Вісник ЖДТУ. 2014. № 2(68). С. 214-218.

\section{References:}

1. Andrade Јого A.S., Duarte Adelaide P.S., Simoes Marta C.N. (2018). Education and health: welfare state composition and growth across country groups. Eastern Journal of European Studies, vol. 9, iss. 2, pp. 111-144.

2. Marchenko, O., \& Sydorenko, N. (2019). Higher education in the globalized world: modern trends in management, funding and quality assurance. Economic Annals-XXI, no. 179 (9-10), pp. 53-65. doi: https://doi.org/10.21003/ea.V179-05

3. SOCIS - tsentr sotsialnykh ta marketynhovykh doslidzhen [Center for Social and Marketing Research]. Access mode: https://socis.kiev.ua/ua (accessed 2 November 2020).

4. Zinovchuk V. (2016). The Matrix Methods and Models in Marketing Analysis and Planning [The Matrix Methods and Models in Marketing Analysis and Planning]. Visnyk Zhytomyrskoho natsionalnoho ahroekolohichnoho universytetu, no. 1(54), pp. 20-29.

5. Artykutsa N.V. Innovvatsiyni metodyky vykladannya dystsyplin u vyshchiy yurydychniy osviti [Innovative methods of teaching disciplines in higher legal education]. Access mode: http://ekmair.ukma.edu.ua/bitstream/handle/123456789/2424/ Artikutsa_Inov.pdf (accessed 5 November 2020).

6. Bystrova Yu.V. (2015). Innovatsiyni metody navchannya u vyshchiy shkoli Ukrayiny Pravo ta innovatsiyne suspilstvo [Innovative teaching methods in the higher school of Ukraine Law and innovative society]: elektron. nauk. vyd., no. 1(4). Access mode: http://apir.org.ua/ wp-content/uploads/2015/04/Bystrova.pdf (accessed 11 November 2020).

7. Budnik O.M. (2017). Metodolohichni aspekty vykladannya marketynhu u vyshchomu navchalnomu zakladi [Methodological aspects of teaching marketing in higher education]. Hlobalni ta natsionalni problemy ekonomiky. Mykolayivskyy natsionalnyy universytet imeni V.O. Sukhomlynskoho, no. 16, pp. 278-280.

8. Horobets I.A., Makovska H.Ya. (2018). Innovatsiyni tekhnolohiyi u vykladanni inozemnoyi movy profesiynoho spryamuvannya [Innovative technologies in teaching a foreign language for professional purposes]. Molodyy vchenyy, no. $3.2(55.2)$, pp. $56-59$.

9. Hrytsak N. (2018). Innovatsiyni pidkhody do vyvchennya zarubizhnoyi literatury u vyshchiy shkoli [Innovative approaches to the study of foreign literature in high school]. Osvitolohichnyy dyskurs, no. 1-2 (20-21), pp. 188-199.

10. Innovatsiyni tekhnolohiyi navchannya (2017) [Innovative learning technologies]: navch. posibn. dlya stud.vyshchykh tekhnichnykh navchalnykh zakladiv / vidp. red. Bakhtiyarova Kh.Sh. Kyiv: NTU, 172 p.

11. Korzhov G. (2020). Methods of sociological research. Marketing in Ukraine, no. 4, pp. 19-22.

12. Kravchina T.V. (2018). Types of interactive methods of teaching English for tudents of technical specialties. Open educational e-environment of a modern university. Electronic scientific professional publication, no. 5, pp. 140-145.

13. Klyap M. (2015). Innovatsiyni metody navchannya u VNZ yak instrument internatsionalizatsiyi vyshchoyi osvity Ukrayiny [Innovative teaching methods in higher education as a tool for internationalization of higher education in Ukraine]. Vyshcha osvita Ukrayiny, no. 4, pp. 45-53.

14. Kozak L.V. (2014). Doslidzhennya innovatsiynykh modeley navchannya u vyshchiy shkoli [Research of innovative models of teaching in higher education]. Osvitolohichnyy dyskurs, no. 1(5), pp. 95-107. Access mode: http://nbuv.gov.ua/UJRN/ osdys_2014_1_11 (accessed 22 October 2020).

15. Ovcharuk O.V. (2004) Kompetentnisnyy pidkhid u suchasniy osviti: svitovyy dosvid ta ukrayinski perspektyvy [Competence approach in modern education: world experience and Ukrainian perspectives]. Kyiv: K.I.S. (in Ukrainian)

16. Lilyk I.V. Dosvid vprovadzhennya interaktyvnykh metodyk vykladannya marketynhu. [Experience in implementing interactive methods of teaching marketing]. Access mode: https://core.ac.uk/download/pdf/32619251.pdf (accessed 16.10.2020).

17. Palamar, S., \& Naumenko, M. (2019). Storytelling in the professional training of future teachers: modern tools. Open educational e-environment of a modern university. Electronic scientific professional publication, no. 7, pp. 48-55. https://doi.org/10.28925/2414-0325.2019.7.5/

18. Pronsky E.A. (2016). Interaktyvni metody vyvchennya marketynhu [Interactive methods of studying marketing] / E.A. Pronsky; Science. ker. L.Yu. Sager. Economic problems of sustainable development. Materialy mizhn. nauk.-prakt. konf. im. prof. Balatskoho O.F. Sumy: SumDU, no. 2, pp. 69-71.

19. Romanova P.A. (2007). Pobudova navchalnoyi tekhnolohiyi: indyvidualno-typolohichnyy pidkhid [Construction of educational technology: individual-typological approach]. Psykholoho-pedahohichni aspekty realizatsiyi suchasnykh metodiv navchannya u vyshchiy shkoli. Kyiv: KNEU. (in Ukrainian)

20. Ryasnykh E., Savchenko O. (2018). Marzhynalnyi pidkhid do analizu asortymentu produktsii pidpryiemstva [Marginal approach to the analysis of the product range of the enterprise]. Marketing in Ukraine, no. 6, pp. 35-44.

21. Tsyganok V.M., Budnik O.M., Gulya Yu.V. (2014). Teoretyko-metodolohichni aspekty implementatsiyi osnov marketynhu $\mathrm{v}$ navchalnyy protses [Theoretical and methodological aspects of the implementation of the basics of marketing in the educational process]. Visnyk $Z H D T U$, no. 2(68), pp. 214-218. 
Будник О. Н.

Полесский национальный университет

\title{
КОМПАИМЕНТАРНОЕ СОЕАИНЕНИЕ КААССИЧЕСКИХ И ИННОВАЦИОННЫХ МЕТОАОВ ПРЕПОААВАНИЯ В СОВРЕМЕННОМ ПРОФЕССИОНААЬНОМ ОБРАЗОВАНИИ
}

\begin{abstract}
Резюме
Основным приоритетом современного высшего образования является его направленность в сторону европейского образовательного пространства, в связи с чем вместе с классическими научными приемами существенно усиливается роль инновационных и интерактивных методов, а также методик обучения. Вариативность инноваций в образовании способствует проведению занятий на качественно новом уровне, что формирует у студентов навыки критического мышления, дает им возможность научиться собирать необходимую информацию, систематизировать и анализировать ее, решать сложные задания, развивать логику и стратегическое мышление, использовать и развивать собственный потенциал. Особенно актуальной при преподавании дисциплин маркетингового цикла является методика роботы в фокус-группах, использование которой позволяет студентам әффективно взаимодействовать и, как результат, формировать новые, интересные и нестандартные предложения решения сложных заданий.

Ключевые слова: классические научные приемы, инновационные и интерактивные методы преподавания, критическое мышление, фокус-группы.
\end{abstract}

Budnik Olga

Polissya National University

\section{THE COMPLIMENTARY COMBINATION OF CLASSICAL AND INNOVATIVE TEACHING METHODS IN THE MODERN PROFESSIONAL EDUCATION}

\begin{abstract}
Summary
The main priority of the modern higher education is its orientation to the European educational space, therefore, along with classical scientific methods, the innovative and interactive teaching methods and techniques role is greatly enhanced. The variability of innovations in the education contributes a qualitatively new level, which develops students' critical thinking skills, allows them to collect the necessary information, as well as systematize and analyze it, to solve complex problems and develop logic, strategic thinking, apply and discover their potential. The special attention is paid to the problem of the deep marketing knowledge getting. It is noted that Ukrainian companies nowadays need to purchase advanced technologies, the latest machinery and equipment, but, at the same time, they feel the lack of specialists who are able to apply them. Therefore, the various fields and economy sectors professionals training is an urgent task of modern education. It also emphasizes the necessity of the classical and innovative methods combination. The article covers methodological foundations of marketing new modern methods introduction. The possibilities and benefits of the focus groups are specified. The importance of the both classical and innovative approaches existence and combination is determined. The peculiarity in the focus groups working through the main tasks such as market's analysis, trade and price policy studying, enterprise logistics and communication policy research are considered. The necessity of the student's own vision of the problem situation solving is emphasized. It also outlined an extremely important role of the highly qualified specialists training because the modern employers prefer young professionals with the experience and possibilities in performing their duties and their collective communication skills in a real business environment. It reviewed that the complementary combination of the classical and interactive methods will change the positions of both teachers and students, as they will be able to become equal subjects of interaction in the educational space.

Keywords: the classical scientific methods, the innovative and interactive teaching methods, the critical thinking, the focus groups.
\end{abstract}

